\title{
Enacting the contested past: conflict narratives in educational spaces
}

\author{
Sunčana Laketa ${ }^{1}$ and Dilyara Suleymanova ${ }^{2}$ \\ ${ }^{1}$ Department of Geography, University of Zurich, Zurich, Switzerland \\ ${ }^{2}$ Department of Social Anthropology and Cultural Studies, University of Zurich, Zurich, Switzerland \\ Correspondence to: Sunčana Laketa (suncana.laketa@geo.uzh.ch) and Dilyara Suleymanova \\ (d.suleymanova@access.uzh.ch)
}

Received: 2 August 2016 - Revised: 25 November 2016 - Accepted: 29 November 2016 - Published: 2 January 2017

\begin{abstract}
The article analyzes unfoldings and enactments of narratives on a politically divisive past in educational spaces of two multi-ethnic settings - the Republic of Tatarstan and Bosnia and Herzegovina. We explore how the contested past is represented within official school curricula and how it unfolds in concrete school settings. In each case we have a historic event that is a politically divisive and contentious issue. Though one of these historical events lies far back in history (1552) and the other is more recent (1992-1995), in both cases the contested past is being silenced in the official history curricula. The paper is guided by the following question: in what ways does a past that is muted within a history curriculum continue to speak and structure the relationships of the school present? In order to answer this question, we situate our work within the literature on ethnographies of education, as well as the relatively new but burgeoning field of inquiry on emotional geographies and anthropologies of education. Drawing on ethnographic fieldwork in these two settings, we argue that the narratives on the violent past form and divide national communities not only through divergent views and interpretations of the historic event by the groups involved but also through strong emotional attachments to these narratives. We conclude by calling for a sustained engagement with emotions in educational settings as sites of embodiment that work to negotiate and actively rework top-down educational narratives, especially when considering the processes of identity-building through school spaces.
\end{abstract}

\section{Introduction}

As a hegemonic apparatus of the state (Althusser, 2006), education plays a crucial role in modern nation-building processes and in the formation of national identities. This role of education in nation-building is expressed not only in its hold over vast populations that are subjected to obligatory schooling but also in power structures that are inscribed into educational discourses and practices (Bourdieu, 1991). Through their ubiquitous yet normalized presence in daily lives of young people, schools work to create national citizenry in both banal and blatant ways (Benwell, 2014; Müller, 2011). The creation of national communities in schools rests on manifestations of what Billig (1995) terms "banal nationalism", meaning mundane ideological habits and objects that saturate school spaces and enable nationalism to be reproduced, such as flags, signs, national curriculum subjects, and so on (Collins and Coleman, 2013; Korostelina, 2013; Ploszajska, 1996). At the same time, through more overt and "blatant" national narratives or "myths" on the formation of the nation or on certain traumatic historical events, the educational system socializes children into national communities (Bieber, 2002; Campbell, 1998; Cairns and Roe, 2002; Simić, 2000; Smith, 1999).

Hammack and Pilecki (2012, p. 78) define narrative as "the sensible organization of thought through language, internalized or externalized, which serves to create a sense of personal coherence and collective solidarity to legitimize collective beliefs, emotions, and actions". Narratives exist both on the collective level (national, historic narratives), as socially constructed and shared representations of particular events, and on the individual level (personal narratives, life stories, biographies). Conflict narratives that offer a particular inter- 
pretation of the traumatic, violent past play a powerful role in constructing communities, as well as establishing and reproducing of "us" versus "them" dichotomies (Salomon, 2004, p. 284). Thus, as Pandey (2001, p. 4) has observed, "in the history of any society, narratives of particular experiences of violence go towards the making of "community".

The article analyzes the role of such narratives in two complex educational settings - Tatarstan and Bosnia and Herzegovina $(\mathrm{BiH})$. Specifically, in these two multi-ethnic and multi-religious sites we are witnessing a situation in which a politically divisive event is avoided within the official history curricula but still continues to play an essential role in (re)creating national communities through schooling. In order to interrogate this seeming contradiction, the paper is guided by the following question: in what ways does a past that is muted within a school history curriculum continue to speak and structure the relationship of the school present?

While official, top-down educational discourses, as expressed through curricula, textbooks, or school rituals, are important in examining official state strategies in shaping national citizenry and national values, they cannot alone determine what happens in schools and what views, narratives, and practices pervade school life and thus influence the formation of pupils' subjectivities. As Adely (2012, p. 20) asserts, schools as state institutions are rarely completely successful in their efforts to control production of knowledge through public education, "as they must contend with other forces in and around school". Literature on geographies and anthropologies of education highlights the value of ethnographic engagement with school practices that go beyond curriculum or textbook analysis in order to examine what is going on inside the school - during and between lessons, on playgrounds, in cafeterias, or in bathrooms (Jeffrey, 2010; Holloway et al., 2010; Hromadžić, 2011; Levinson, 1996; Mills and Kraftl, 2016; Reed-Danahay, 1996; Willis, 1981). These studies have revealed that there is much more contestation, negotiation and resistance going on in schools, thus drawing attention to the agency of teachers and students in shaping classroom spaces (Adely, 2012; Bénéï, 2008; Willis, 1981). Thus, methodologically and theoretically we situate ourselves within this body of literature and seek to contribute to the debate by highlighting the role of emotions and embodiment in negotiating conflictual educational landscapes.

Human emotions, defined as complex psychophysiological and mental states that involve feeling, have emerged as a significant area of study in social sciences in the past decade (Ahmed, 2004; Cough and Halley, 2007). Emotions have long been marginalized in the study of education as well, with emotional geographies and anthropologies of education being a relatively new but burgeoning field of inquiry (see Special Issue in Emotion, Space and Society 2011, as well as the work of Michalinos Zembylas, 2007, 2008). In this paper we engage with an understanding of emotions as social phenomena rather than emotions seen as inward experiences of individuals. Specifically, drawing from the writings of Sara Ahmed (2004) on the cultural politics of emotions we address the way emotions circulate between bodies and things in ways that are constitutive of and constituted by the everyday practices of schooling. In other words, rather than focusing on what emotions are, we analyze what work they do in forming social and political collectivities. As Zembylas (2007, p. 293) has argued that "Emotions in the classroom are not only a private matter but also a political space in which students and teachers interact with implications in larger political and cultural struggles". Expanding on recent fruitful engagements with emotions and affect in the field of education (Bekerman and Zembylas, 2011; Bénéï, 2008; Kenway and Youdell, 2011; Mills and Kraftl, 2016; Zembylas, 2007, 2008), and drawing on our ethnographic fieldworks ${ }^{1}$, we highlight the role of emotions in the enactments of conflictual past within educational settings.

Guided by these theoretical considerations, this paper brings two case studies as illustrations of the ways that narratives about the violent past unfold in school settings in the context where official addressing of these issues is muted and foreclosed for open classroom debate. It is important to note that this article is not a comparative study between our two study sites - Tatarstan and $\mathrm{BiH}$ - as a comprehensive comparative analysis would exceed the purpose of this article. Rather, we use these two different sites as examples of conflicting educational landscapes and we seek to bring them in communication with one other, for following specific reasons. First and most important for our analysis, in both cases we have a violent past event that is ethnically divisive - the 1552 conquest of Kazan in the case of Tatarstan and the 1992-1995 war in the case of $\mathrm{BiH}$. Both events are sensitive issues to be addressed in the class where divergent interpretations of this event could lead to deepening of ethnic cleavages. Second, in both cases we encounter the fact that these two specific events are insufficiently addressed within the school curricula. Instead of an open discussion and debate of the issue, the strategy is rather to avoid it altogether. Third, both educational systems historically played a key role in the construction of socialist communities, even though the development of socialism in USSR and Yugoslavia took rather different paths (Avis, 1987; Torsti, 2009; Verdery, 1996). Today, both systems build on that legacy of using schooling as a primary mean of shaping national communities. The contemporary school education thus becomes an arena of contested nation-building projects where various actors (both national and international in the case of $\mathrm{BiH}$ and federal and regional actors in the case of Tatarstan) compete over the power to

\footnotetext{
${ }^{1}$ It is important to note the differences in methodologies used in two cases: the Tatarstan case study comes from a school ethnography research, while the $\mathrm{BiH}$ case study comes from an ethnography of the city with the analysis of school as embedded in the overall urban and political geography.
} 
shape national selves through, among others, control over school curricula.

The paper proceeds in the following manner. The first section, written by Suleymanova, addresses the case of Tatarstan starting with a brief outline of its political and educational settings, highlighting particularly the significance of the conquest of Kazan (1552) for the Tatar national narrative. Suleymanova goes further to provide insights that go beyond the official educational discourse into the everyday practices of the school. Particularly, she presents a vignette that illustrates the way a local teacher brings into the classroom the narrative of the conquest of Kazan in a deeply personal and emotional way. The second section, written by Laketa, starts with a similar outline of the educational context in contemporary Bosnia and Herzegovina with a focus on the 19921995 war and its role in shaping the system of education. Laketa then puts forth a vignette as an entry point into the everyday spaces of the school where students engage with this violent past through complex emotional negotiations and contestations of the educational and political setting. Finally, we come together to complete our thoughts, as well as to open discussion on further investigations into the problematic. We conclude by linking these two cases studies in the argument we seek to advance on the role of emotions in reproducing conflictual past. We argue that the narratives of contested past form and divide national communities not only through divergent views and interpretations of historic events by the groups involved but also through strong emotional attachments to these narratives and memories. The point of such narratives is then "less to tell us what 'exactly' happened than what it felt like to experience an event" (Bekerman and Zembylas, 2014, p. 55, emphasis in text).

\section{The case of Tatarstan: competing nationhood claims}

The Republic of Tatarstan is a multiethnic region of Russia and is often showcased as an example of peaceful coexistence of two national groups, Tatars and Russians, and two world religions, Islam and Christianity, respectively ${ }^{2}$. After the dissolution of USSR and a period of political and social instability with developments that could potentially erupt into a larger conflict, political solution was found to the aspirations of the republic towards political independence making it an example of a successful resolution of competing nationhood claims (Gorenburg, 2003; Graney, 2010).

The main challenge for the republican government since then was to balance between the interests and aspirations

\footnotetext{
${ }^{2}$ According to the latest Russian census results (2010) the population of Tatarstan comprises $53 \%$ Tatars, $39 \%$ Russians, and $8 \%$ representatives of other ethnic groups. Results available at http://www.gks.ru/free_doc/new_site/perepis2010/croc/perepis_ itogi1612.htm.
}

of the Tatars as a "titular"3 nationality and the interests of Russians, who make up almost half of the population and look towards the federal center in support for their claims ${ }^{4}$. These, sometimes divergent, interests have been unfolding particularly in educational, cultural, and linguistic spheres (Graney, 2010; Suleymanova, 2017). Thus, the fact that the Russian and Tatar languages were proclaimed as official languages of the republic and had to be studied in equal amounts at schools have been contested by certain segments of the Russian-speaking population (Suleymanova, 2017).

Even though Tatarstan is incorporated into the Russian system of education and is subject to Russian educational regulations, it continuously attempts to create and retain spaces where Tatar ethno-national as well as regional (related to Tatarstan as a political entity) discourses can be transmitted, especially since official Russian school curriculum and textbooks do not adequately reflect the ethnic diversity of the country (Ismailov and Ganieva, 2013; Khasanova, 2005; Shnirelman, 2011). Moreover, from the 2000s onwards there was a process of increasing unification and centralization of school curricula across Russia for the sake of strengthening patriotic sentiments and fostering identification with the Russian nation-state; the process left almost no space in the curriculum for the representations and narrations of nonRussian minority identities (Piattoeva, 2009; Prina, 2015; Suleymanova, 2017; Zamyatin, 2012).

In the context of Tatarstan, one such alternative narrative that symbolizes and expresses the idea of a long-term resistance to the Russian rule is the narrative of the conquest of the Tatar city of Kazan in 1552 by the Russian Tsar Ivan the Terrible. Even though the event lies far back in the Middle Ages, its symbolic and political significance stretches far beyond this period as it is manifested in political struggles between the center and the region (Derrick, 2012; Graney, $2010)^{5}$.

On 15 October 1552 the Kazan Khanate - a medieval Tatar state, successor of the Golden Horde, situated on the confluence of the Volga and Kama rivers - was conquered by the Russian Tsar Ivan the Terrible after several days of siege. After the conquest of the city, Kazan was resurrected as a Russian Orthodox city where with few exceptions Tatars were not allowed to settle. For the expanding Muscovite state this conquest was of strategic significance: it allowed for the col-

\footnotetext{
3“Titular nationality" (titul'naya natsionalnost') is a term used in the Soviet Union for those ethnic groups after which the ethnically designated autonomous republics were named (this ethnic group did not have to represent the majority within these republics).

${ }^{4}$ These concerns are mostly related to the preservation of the status and the rights of the Russians in the republic that they enjoyed since the Soviet period (for example their representation in political bodies as well as cultural and linguistic claims).

${ }^{5}$ We have other examples of historical events lying far back in history with a great significance for the stories of nation-building, such as the Battle of Kosovo in 1389, central to the Serbian national narrative (Bieber, 2002).
} 
onization of vast territories eastwards of Kazan, thus laying grounds for the forthcoming Russian Empire (Kappeler, 2001). In the Tatar national narrative, as expressed in various Tatar literary and political texts, the conquest of Kazan is a tragic event that not only put an end to the independence and political autonomy but also destroyed the rich cultural heritage of the Kazan Tatars (Derrick, 2012).

The way this historical narrative has been interpreted and represented in the official historiography and in the school education in Tatarstan has changed throughout time. During the Soviet Union, the story of the Kazan Khanate's conquest could be interpreted only in line with the official Soviet position on it as a progressive event that gave Tatars access to rich achievements of the Russian culture (Izmailov, 2003).

It was not until the dissolution of the Soviet Union in 1990 when other visions of the conquest of Kazan could be voiced and represented. Tatar national movement that demanded political autonomy for Tatarstan after the fall of the Soviet Union used the conquest of Kazan as a symbolic and historic legitimization for claims for independence and sovereignty (Derrick, 2012; Graney, 2007). Thus slogans such as "1552 will stay forever in the memory of Tatars" and "We have lost our statehood in 1552 but we will regain it in 1993" figured prominently during mass demonstrations and protests on the eve and after the dissolution of USSR ${ }^{6}$. Thus, since 1989 every year, 15 October is unofficially commemorated as the Memory Day (Khäter kene in Tatar) in Kazan with groups of Tatar cultural and political activists undertaking collective marches through the center of the city and a collective prayer in the Kazan Kremlin (Derrick, 2012).

In the beginning of 2000 s, with an increasing centralization of political powers in Russia, the narrative of Tatars and Russians as antagonistic to each other has been reinterpreted and replaced by a vision of Tatars and the Republic of Tatarstan as firmly integrated into the Russian political and ideological space (Derrick, 2012). The official government of Tatarstan has increasingly distanced itself from the commemoration of the conquest of Kazan and the image of the conquest has been increasingly marginalized in the public discourse (Derrick, 2012). Russian educational reforms (specifically the eradication of the regional component of curriculum in 2007) resulted in, for example, taking out the subject of the history of Tatarstan from the school curriculum in Tatarstan (Suleymanova, 2017; Zamyatin, 2012). Even though the new Russian curriculum structure has significantly curtailed the possibilities of transmitting alternative narratives in the classroom, during my ethnographic fieldwork at schools in a provincial town in Tatarstan I could

\footnotetext{
${ }^{6}$ In November 1992, a group of Tatar nationalists and Muslim activists published an open letter to then-President Shaimiev, claiming that the churches in the Kazan Kremlin were built "on the graves of Tatars their mosques" and demanded a monument in the Kremlin dedicated to the Tatars who died defending it in 1552 (Graney, 2007, p. 21).
}

observe how memories about the past that do not fit easily with official historic representations could be brought into the classroom.

\section{Remembering 1552}

The vignette presented derives from a subset of ethnographic data collected in a small provincial town ${ }^{7}$ in Tatarstan during the 2009-2010 academic year (with subsequent visits in 2011-2013). Ethnographic fieldwork included, among others, observations conducted in a Russian-language school with a body of around 500 students. The setting was a 10th grade classroom with a mixed body of students which I followed throughout the academic year, regularly visiting, observing and taking notes during their classes, doing qualitative interviews with pupils and teachers as well as having informal conversations with them in the flow of school life, attending and documenting curricular and extracurricular school events 8 .

Shortly after the arrival to this small provincial town, I realized how proud and conscious people were of the ethnic diversity of the area and the peaceful co-existence of various ethnic groups. Joint public celebrations of major ethnic festivities (Russian, Tatar, Udmurt, and Mari), mixed marriages, and churches next to mosques were often brought up as illustration of the harmonious relationships between various ethnic groups despite major differences in religion, language, and traditions. Such stories were partially rooted in the Soviet discourse of "internationalism", a common way to speak about ethnic differences as unimportant and ethnic relations as unproblematic. Indeed, most of the residents have highlighted how Muslim and Christian holidays are being celebrated together in a circle of neighbors and friends. Indeed, my initial observations gave an impression that ethnicity was not the main concern of children and youth and mixed friendships as well as marriages were common. However, as it is often the case, ethnic stereotypes and prejudices about the "Other" have been pervasive and thrived along the rhetoric of the "peaceful living together".

The same kind of unifying approach was typical for the school education. Most of schools in this small town were

\footnotetext{
${ }^{7}$ The name of location remains undisclosed for ethical considerations.

${ }^{8}$ Participant observations during the lessons were largely not audio or video recorded due the explicit request of the teachers, so mostly observations were written down as field notes. Formal qualitative interviews were conducted with educational staff (teachers, school principals) but also with technical staff (nurses) as well as with pupils. Apart from this ethnographic research at schools, the study was also conducted in Kazan, the capital of republic, and involved analysis of educational materials, textbooks, regulations, and interviews with educational experts and functionaries. Field notes, interview transcripts, and educational materials (textbooks, curriculums, and others) were analyzed in accordance with qualitative methods such as grounded theory (Strauss and Corbin, 1998).
} 
Russian-language schools (instructed in the Russian language) and had ethnically mixed body of students. Curriculum, tests, textbooks, and other educational materials (available only in the Russian language) were handed down from the federal educational ministry in Moscow. There was an increasing pressure on the school to focus on the transmission of Russia-centered identity narratives (Piattoeva, 2009; Suleymanova, 2017), a situation created by the eradication of the regional component from the school curriculum, which has foreseen special curricular hours on subjects and contents related to the region (for example for teaching local languages and histories), and by the introduction of new examination procedures which prohibited pupils to take their exams in languages other than Russian (the so-called Unified State Examination). Thus, there is presently no such subject as the history of Tatarstan in the school curriculum and pupils can learn something about the history of their region only within the framework of the Russian history course. The only lessons that could be retained from this regional curriculum component were the lessons on Tatar language (including Tatar literature), which also use regionally produced textbooks 9 .

I met Farida Khalimovna ${ }^{10}$, a teacher of the Tatar language who was native to the area, in one of Russian-language schools were I conducted my fieldwork. She grew up and was educated in the Soviet Tatarstan and has been teaching Tatar language and literature in this school for many years, but was becoming increasingly concerned with the situation of Tatar language teaching in school education. As schools increasingly dismantled educational initiatives related to the transmission of minority cultural identities and languages and the knowledge of the Russian language became the foremost priority in the lives of pupils, she feared the loss of Tatar language and identity and often addressed these issues in her classes.

She allowed me to observe her classes and, usually, I sat in the back of the classroom (after some period of research pupils and teachers grew accustomed to my presence), listening, making notes, and occasionally taking part in discussions. It was a class of 10th grade pupils (aged 14-15) with a mixed ethnic composition (mostly Tatars but also Russians and Udmurts). I mostly visited Tatar literature lessons that took place once a week, where I expected more discussion on various cultural issues to take place. Within the syllabus and textbooks of the Tatar literature, one to two lessons could be dedicated to the literature of the period of the Kazan Khanate.

\footnotetext{
${ }^{9}$ The lessons of the Tatar language take place usually four times a week, which is a considerable part of the school curriculum. For these classes pupils are often divided into "Tatar" (native-speaking) and "Russian" (non-native-speaking) groups, though this division happens mostly based on ethnicity and not on actual language competence.

${ }^{10}$ The name and surname of the teacher were changed for the reasons of anonymity.
}

It is here that the story of the conquest of Kazan could be brought up by the teacher, as indeed happened during one of the lessons ${ }^{11}$.

Farida Khalimovna started her lesson with narrating how flourishing and prosperous the period of the Kazan Khanate was in the history of Tatars and how advanced the cultural, religious, and architectural achievements of the Kazan Tatars were. This period, which was the highest point in the development of Tatars, was terminated by the conquest of Kazan. In this sense, the conquest of Kazan was the most tragic and traumatic event in the Tatar history. She explained that Kazan was taken with particular brutality: most of the city was destroyed and the population was either killed or expelled. New rulers tried to eliminate all Tatar traces in the city, building Orthodox churches on the places of destroyed mosques and plundering sacred shrines, cemeteries, and precious libraries. At the same time, she avoided saying that the "Russian" troops conquered Kazan and talked about the troops of Ivan the Terrible instead ${ }^{12}$. As a result of this conquest, she continued, a nation with a rich historical, cultural, and religious tradition had been colonized. She also mentioned the violent Christianization campaigns that followed the conquest when Muslim Tatars were forced to give up their faith and convert to Christianity. While she was narrating, one could observe how emotionally touched she was by this history. Pupils sat and listened in silence.

These experiences of persecution did not end up with the conquest of Kazan however. The teacher wanted to emphasize the relevance of this distant event to the present day as the Tatar nation continues to experience discrimination in terms of religion and language. Thus, she told pupils the story of her own childhood as a pupil in a Soviet school when she was precluded from practicing her religion. She told how pupils who fasted during the month of Ramadan or celebrated Muslim holidays were publicly humiliated in front of the whole class or how they were forced to eat if they were fasting. The tone of her voice hinted at emotional involvement as she recounted these experiences. She emphasized that in a democratic state it should be possible to speak freely about things that happen, stating that "We have rights and we can learn all these stories that no one told before". Thus the stories of persecution, like the conquest of Kazan or her personal experiences of Soviet childhood, could be retold in the classroom. She took the initiative to address these issues despite the fact that these matters were avoided by the official curriculum.

\footnotetext{
${ }^{11}$ Textbook on Tatar literature she used also shortly described the events of the conquest of Kazan.

${ }^{12}$ It must be mentioned that there were rivalries between the Tatar populations belonging to different khanates and a certain group of Tatars has been fighting on the side of Ivan the Terrible and was involved in planning and operating the conquest of Kazan.
} 
After the class I approached her and we spoke a little bit more on that topic. She was aware that this story could spur conflict dynamics in the classroom and stated,

It is difficult to talk about such issues as the conquest of Kazan in the Russian-speaking group. You have to be very correct and think about every word you use. Kids are very different now. They are not afraid to express their opinion and if you say something incorrect they will be open in their reaction, will talk about their rights. It is much easier to work in a Tatar group. You can speak calmly about these issues and do not have to think about hurting national feelings of others.

Thus she avoided speaking in terms of "Russians against Tatars", presenting it rather as a matter of politics and highlighting the fact that some Tatars also took part in the conquest of Kazan. However, she affirmed that what she really thinks about this event is different from what she says in the classroom:

Even though, honestly, I think that this was not just politics. It was genocide of the whole nation, a policy of its purposeful annihilation. But I cannot tell that to them because of the reaction that might come.

The narrative of the conquest of Kazan that was invoked by the teacher is an ethnically sensitive one that could divide classrooms along ethnic lines. Even though the teacher consciously avoided talking about the "Russians" versus "Tatars", the discourse on victims and perpetrators that are ethnically and religiously different has been central to her narrative. Most importantly, the narrative invoked students to remember the distant traumatic past that, despite lying back in centuries, has repercussions for today. She brought in her own experiences as illustrations for the ways discrimination continues to the present day - so that past unfolds in the present and cannot be forgotten ${ }^{13}$.

Even though the teacher has not witnessed the event herself, she experienced it in deeply personal and emotional ways. Analyzing the ways memories of collective trauma are transmitted, anthropologist Maurice Bloch (1997) illustrates through an example of a Zafimaniry village in Madagascar how recollection of particular traumatic events evokes certain "emotional and empirical experiences" also among those who did not experience this past directly, for example children (Bloch, 1997, p. 121). These examples show how, without being directly experienced, memories about traumatic past can be integrated into one's own personal memories and narratives (Middleton and Edwards, 1990).

\footnotetext{
${ }^{13}$ The conquest of Kazan was addressed not only by this teacher of the Tatar language but also by some other teachers, for example during the lessons on English language and on social sciences.
}

The way the teacher brought this story into the classroom reveals the intimate connection between the narrative of the conquest of Kazan and her personal experiences of the Soviet childhood. Thus, collectively shared narratives of the distant past have repercussions for the ways personal past and present are experienced and interpreted. This vignette also highlights how the agency of local teachers unfolds within the classrooms, even in the context of increasing curriculum control from the federal center. Presenting her personal story of persecution, the teacher actively brings in the silenced past into the classroom and transmits alternative narrations and experiences. Such emotional enactments reproduce the contested past in the present, but they also work to challenge the official agenda of the educational system aimed at shaping homogenous Russian citizenry. In this sense, such enactments play an important role in the processes of contested minority nation-building amidst tightening centralization efforts of the Russian state.

\section{Bosnia and Herzegovina: education at the front line}

The issue of education for many presents one of the most significant impediments toward lasting peace and reconciliation in post-conflict BiH (Hill, 2011; Hromadžić, 2011; Torsti, 2009; Turjačanin et al., 2009). In the slow recovery of the country from the devastating war, the political divisiveness built upon the multicultural fabric of the society continues to loom large. The contemporary system of education with ethnically segregated schools and classrooms in many ways epitomizes this political divisiveness. In order to understand the current ethnical division in schools and the lack of common national curriculum, it is necessary to briefly describe the circumstance of the 1992-1995 war in $\mathrm{BiH}$ as well as analyze the impacts of the political system founded in the aftermath of the war.

$\mathrm{BiH}$ was one of the six republics of the Socialist Federal Republic of Yugoslavia and also the most culturally, ethnically, and religiously diverse republic of this multiethnic socialist federation. However, the violence that erupted on its territory in early 1992 shook some of the very foundations upon which the republic was founded. The war was waged as a battle for power and territory by competing political oligarchies claiming to represent interests of three main ethnic groups in $\mathrm{BiH}$ - Croats, Serbs, and Bosnian Muslims (also called Bosniaks). The political leaders and their respective armies embarked on an ethno-nationalist project of producing ethnically homogenous areas void of members of other ethnicities, a project which included mass murder, displacement, systematic rape, and the destruction of much of the country's urban public spaces (Toal and Dahlman, 2011). The effects were profound not only in terms of staggering human loss but also in terms of a collapse of social system of values with education being one of the first targets of this 
new ideology of ethnic nationalism (Torsti, 2009). Specifically, in socialist times before the breakup of Yugoslavia all children in $\mathrm{BiH}$ sat in the same classrooms and studied the same textbooks regardless of their ethnic, national, or religious identity. Indeed, school and the entire education system played a significant role in building the Yugoslav ideology of "brotherhood and unity" (Bartulović, 2006; Torsti, 2009). This, however, dramatically changed during the very first year of war. In a struggle for territorial domination in $\mathrm{BiH}$, each army, as it was taking hold of a certain territory, would also take control of the schools and the school curriculum in that area. The Bosnian Serb military imposed the curriculum developed in neighboring Serbia, the Bosnian Croat army introduced the curriculum from neighboring Croatia, while the territories controlled by the Bosniak-led army developed their own new Bosnian curriculum (Torsti, 2009). Therefore, in addition to human lives and properties, education proved to be one of the main military targets of the ethno-nationalist project.

The war officially ended in 1995 yet the aftermath has left $\mathrm{BiH}$ as a politically, socially, and spatially divided country. The country's constitution founded upon the Dayton Peace Agreement continues to have one of the most devastating impacts in the field of education (Mujkić, 2011). One of the most notable characteristics of the educational system in contemporary $\mathrm{BiH}$ is its extreme division among country's political-administrative units, including divisions between two governing "entities" and one separate "district" with a further division of a one "entity" into several independently run "cantons". As a result, for example, today the small country of $\mathrm{BiH}$ has a staggering 12 different ministries of education $^{14}$. However, as Aleksandar Hemon (2012) correctly notes, "what appears as inept madness is in fact a method", as this decentralization is crucial for the context of a segregated education that was initiated during the first year of war and that continues, with some modifications, to this day.

Besides the changes in the system of education and the curriculum that reflect the divisive nature of ethno-nationalist projects, further segregation was achieved through physical separation as well. Namely, in most schools in BiH children and youth of three main ethnic groups are educated in separate spaces. Sometimes those spaces are different buildings, but sometimes children of different nationalities share the same building but attend separate classes or entire shifts (the so-called "two schools under one roof" concept). These segregating practices are continually criticized for violation of human rights and other ethical values, and for advancing discrimination and increasing ethnic distance, yet these practices continue, mostly due to main political leaders supporting the status quo (Mujkić, 2011; Turjačanin et al., 2009).

In order to hinder some overtly nationalist aspects of the educational system, there is a significant pressure coming

\footnotetext{
${ }^{14}$ For a detailed account on the effects of Dayton Peace Agreement on the system of education see Hromadžić 2015.
}

from some international organizations, one of the most notable being Security and Co-operation in Europe (OSCE) mission to Bosnia and Herzegovina. Under the tutelage of OSCE and under the ideology of modernization and democratization, several reforms were initiated in the field of education in $\mathrm{BiH}$, most of them with limited and contradicting effects. For example, beginning in 2004, schools in $\mathrm{BiH}$ have not been allowed to use textbooks from neighboring countries, rather each of the "constituent peoples" had to develop their own independent curricula (OSCE, 2010; Torsti, 2009). However, there is still no common national-level curriculum in $\mathrm{BiH}$. What is more, the textbooks in use in different curricula, especially for teaching the so-called "national" subjects (history, geography, language, and religion), promote isolation of ethnic groups by presenting teaching materials in uncritical, stereotypical, and prejudiced ways that work to undermine social and ethnic cohesion (for a comprehensive overview of different textbook analysis see Husremović et al., 2007; Turjačanin et al., 2009; Torsti, 2009).

Another contradictory measure recommended by the OSCE and the Council of Europe was the introduction of a moratorium on teaching the events of the 1992-1995 war in $\mathrm{BiH}$ in history classes throughout the country. The moratorium on the conflict narrative is to stay in place until Bosnian scholars and historians reach a consensus on teaching this violent past (Karge and Batarilo, 2008; Parliamentary Assembly of the Council of Europe, 2000). While many recognize the importance of open, democratic, and participatory history education of the recent war (Bartulović, 2006; Radušić, 2009), for generations of students the subject is not adequately addressed with main contentions issues such as the massive 1995 killings in Srebrenica remaining muted and closed for classroom discussions. It is important to note that while the recent war is not extensively covered, other past wars and conflicts (especially World War II) are continually presented in biased, one-sided, and ethnically divisive ways (for detailed examples see Husremović et al., 2007).

All this attests that schools in $\mathrm{BiH}$ are a contemporary front line and a site of struggle between not only the three ethno-national political oligarchies but also a host of other international actors and their interests (Laketa, 2015). The following section goes further to introduce voices of the students as active agents rather than passive victims of these (geo)political struggles and it address the way the violent past is evoked, negotiated, and contested in the spaces of the school present.

\section{Where have the years 1992 to 1995 gone?}

The following vignette comes from my ethnographic research, conducted between 2010 and 2014, with the goal of understanding the everyday geopolitical practices of the citizens of the post-conflict city of Mostar. The project began with participant observation on the ways everyday practices are involved in the processes of (un)fixing the notion of eth- 
nic identity in the city, as a way of uncovering the daily negotiations in the city that has been politically and socially divided between Bosniaks and Croats for over 2 decades. During the initial phase of research, through formal and informal contacts I have made, another set of related questions started to emerge. This was in the issue of violence among Mostar's youth and the problems of divided education in Bosnia and Herzegovina. As most of the Mostarians I've talked to expressed various concerns regarding the position of young people in Mostar, and as I witnessed several violent incidents, occurring especially during football matches ${ }^{15}$, I started to focus my attention on Mostar's high school students, who I identified as a particularly vulnerable population in a tense atmosphere of a post-conflict city. Specifically, given the divided system of education that starts from primary school and ranges even up to the university level, young people rarely get a chance to freely communicate across ethnic lines - a situation that promotes fixed notions of ethnic identity, as well as increased antagonism between groups. Besides separation of schools and the very content of education between two main ethnic groups, there is a strong spatial element to the division of education that is materialized in the urban landscape of Mostar. In particular, federal (unofficially Bosniak) curriculum schools are confined to the eastern bank of the river Neretva and Croat curriculum schools are situated along the western bank. There are also a few schools situated along somewhat more ambiguously ethnically designated spaces of the main Boulevard (Laketa, 2016).

In the period between February and November 2013, I visited several of these ethnically divided high schools in Mostar and conducted interviews with senior year students and school personnel ${ }^{16}$. During my conversation with students we discussed things they like and dislike about living in Mostar, as well as the places in the city they like go to and their before and after school routines. Being senior year students, our conversations often revolved around their plans for the future, including family plans, employment, and travel, as well as their pursuit of higher education.

Lucy and Jasa ${ }^{17}$ were friends and classmates in their final year of high school when I met them in the fall of 2013. I talked with them for little over an hour and our conversation switched between everything from their future plans and hopes to the new city mall. At the beginning of our conversation the students quickly expressed their dissatisfaction and frustration with their lives in Mostar and attributed that

\footnotetext{
${ }^{15}$ For an account on violence on Mostar's streets see Moore, 2011.

${ }^{16}$ The interviews were held in schools in any available room or an office, usually the office of the school councillor. We met often on multiple occasions, and the conversations lasted from half an hour to hour and a half, conducted often in groups of two to three students, usually friends, who decided to participate together.

${ }^{17}$ The names are pseudonyms chosen by the participants themselves.
}

dissatisfaction to the political, social, and ethnic cleavages that they have encountered growing up in the city. They recounted multiple divisions that plague the city and their lives, from the everyday to the institutional ones. Moreover, both friends were planning and looking forward to moving to different cities in neighboring countries once they finish high school. Lucy felt particularly confined by ethnic divisions in Mostar and she expressed hope that in another city she will not be judged by her name ${ }^{18}$ as she is in Mostar. Lucy and Jasa continually used "us" versus "them" pronouns throughout the conversation even as they openly denounced such binaries, mostly as a means of describing the spatial and social divisions of the city and the schools. Besides discontent, the two friends discussed many uncertainties and fears associated with occasional outbursts of street violence. "It is as if it's war all over again", said Lucy in response to our conversation on the violent incidents that sometimes occur on the streets, especially during matches between two local football clubs - one Bosniak and one Croat. "But [violence] does not only happen on the street", added Jasa, "they are learning it in schools".

As Jasa made explicit links between street violence and the school, the conversation turned towards the educational system. Lucy then proceeded to open another question: "And why is the ministry of education [of the canton] having to develop separate curricula and two sets of textbooks? One is for Croats and one's for Bosniaks!" Jasa added, "In one they learn that Bosnia is Bosnia and in the other they learn Bosnia is 'Herceg-Bosna'."19 She continued, "And none of them address the war in Bosnia! Where have the years ' 92 to '95 gone? In the clouds! But no matter what they do, it will never be forgotten, never!" The emotional charge of the conversation gained more intensity as the talk turned towards the wars in the 1990s, a subject unprompted by my questions. Both of them quickly discursively detached themselves from the actual events saying that the wars occurred before they were born and thus have no memories of their own. However, the two students showed utter anger at the act of omission of this contested past in the curriculum. Lucy started raising her voice, saying, "What are they thinking!? How can they just take it out from the textbook!?" "You know why?" Jasa replied to Lucy's almost rhetorical question, picking up on her expressed outrage with further raised voice. "Because the same people who are writing the textbooks are the same people who were aggressors in $\mathrm{BiH}$ ! And all those people who committed crimes are now walking free. And this is not happening only in Mostar, it's everywhere, in Sarajevo, in Srebrenica, everywhere where there was genocide. But I will tell my children about it, because they have to know!".

\footnotetext{
${ }^{18}$ Personal names are one of the most visible markers of ethnic identity in $\mathrm{BiH}$.

${ }^{19}$ Nationalistic, historic term representing the Croat state of Bosnia or, in other words, the Croatian territorial aspirations in $\mathrm{BiH}$.
} 
The strong claim that Jasa made about genocide and passing on the knowledge to her future children changed the tone of the subsequent conversation. Prompted by the prospect of children, Lucy and Jasa began to reflect on their own childhoods and difficulties they experienced when trying to comprehend the events of the war. "How do you explain this to a child?" said Lucy quietly. "How do you explain Srebrenica?" Their voices lowered and they expressed worry and dismay, as we further talked about difficulties of comprehending crimes, massacres, camps, and destructions; acts committed before they were born. They began to form complex emotional linkages between the past, the present, and the future. I remained quiet and listening as friends began to bring personal and family histories and their own biographies, reflecting on the traumatic past.

Jasa and Lucy, as well as most of their peers, show a historic consciousness but also make clear that the conflicting past is very present to this day. My conversations with Mostar's youth are aligned with others, mostly journalistic research, on the ways Mostar's youth are held prisoners of the violent past (see Perspektiva-Mostar, 2015). The events that happened during the war were often brought about during my conversations with Mostar's high school students, even as most of them, like Lucy and Jasa, stressed that they have no memories of their own. However, for the generation born after the war ended, the violent past continues to shape their experience of the present and lingers to haunt the spaces of the city and the school (Kuftinec, 1998). The war has significantly altered the social and material fabric of the city that the young people have been brought up in, yet the narrative is muted within the school curriculum with open discussion hindered and confined to places beyond the classroom teachings. The inadequate addressing of the 1992-1995 war creates a contradictory space where the event itself becomes an absent present. In other words, the war is at the heart of the divisive educational system and segregated schooling, yet at the same time it is marginalized in the official school curricula. The vacuum created by this omission creates a space susceptible for further manipulation in ways that perpetuate dividing narratives and other ethno-nationalist myths. The vacuum hinders the democratic process of open discussions of the troubled past and thus undermines the peace-building processes, attesting to the importance of history curriculum in post-conflict reconciliation (Cole, 2007; Oglesby, 2007).

However, as Lucy and Jasa pass harsh criticisms of both their local political and educational institutions as well as the international ones, youth in Mostar cannot be understood as merely passive victims of the wars that occurred in the past and of the educational system built upon it. Rather, they are active agents in re-enacting and transforming the ideals and values passed on to them. This vignette introduces a glimpse into the students' position as agents that contest, subvert, but also reproduce the divisive past. The two students are highly critical toward the country's political elites, the educational system, as well as the current history curriculum. They pass direct questions on the sustainability, validity, as well as the ethics of the prevailing educational approach toward the contested past. They evaluate the current system as highly corrupt and immoral and they see their position as agents that work to actively subvert the silenced past. "It will never be forgotten!" as Jasa exclaimed and showed significant attachment to the war narrative, vowing to pass on this narrative to the future generation (i.e., to her children). Jasa's and Lucy's active political contestations corroborate recent accounts on young peoples' political geographies (Kallio and Häkli, 2011; Laketa, 2015; Skelton, 2010) that stress children and youth's agencies in both formal and informal political activities. In other words, in these debates authors call for sustained engagement with young people's politics, claiming that children and youth are never simple victims of political struggles; rather they are actively involved in them.

The war narrative is not only a site of political contestation by various actors, it is also a site of emotional negotiations. The emotionally charged atmosphere under which my conversation with Jasa and Lucy took place was a way of enacting the contested past in the present moment and it served to establish important linkages between the past, present, and future. These sentiments need to be understood as embodied forms of social and political meaning-making rather than private psychological states (Ahmed, 2004). The feelings of anger were sometimes directed at the political ethno-national elites especially as young women were making a direct link between the current educational system and the past war crimes and genocide, as well as current street violence. In contrast, the anger worked also to reproduce the familiar nationalist narratives between "us" and "them" as "victims" and "perpetrators". Through shared anger students were able to negotiate the contested past in the school space, but also importantly these emotions worked to create a social community through shared condemnation of the past's erasure. The forming of the somewhat new social and political community in that space was further sustained through shared emotions of attachment to the war narrative as highly implicated in their family biographies and collective memories (for a further discussion on the role of emotions and affect in creating political communities in Mostar see Laketa, 2016).

\section{Discussion and implications}

Both settings - Tatarstan and Bosnia and Herzegovina - can be characterized as examples of contested nation-building projects where narratives on the violent past are implicated in political struggles and strategies to control collective and individual memories and emotions, similar to other examples around the world (Bekerman and Zembylas, 2014; Cole, 2007; Zhurzhenko, 2011). Trying to control and determine the ways past and consequently national community is imagined, political authorities exercise their powers over 
the school curriculum and over the ways history is taught. However, even if such conflictual pasts are being avoided or silenced by school curricula, this does not mean that they disappear from the educational spaces (Drozdzewski, 2012). The vignettes provide brief outlooks on the ways muted histories find their way into the spaces of school - through the agency of teachers in case of Tatarstan and of students in case of Bosnia and Herzegovina.

These case studies demonstrate not only that this past is highly politicized but also that it is deeply implicated into personal histories, biographies, and emotional experiences of the actors concerned. These lifeworlds are sites of intense embodiment demonstrating that emotions are inextricably linked with politics and power (Ahmed, 2004; Zembylas, 2008). Thus, both cases testify to the crucial role of emotions in understanding the way contested past narratives are enacted in the present. Our methodological focus on the mundane encounters and practices within the educational setting allowed us to grasp the importance of sometimes subtle, as well as not so subtle, emotional doings and sayings. Such intricacies would be lost if our focus were exclusively on the curricula as official discursive framings of a contested narrative. In both cases it is through strong emotional intensities that the past is materialized in the present moment in ways that helps the students and teachers give meaning to their everyday social and educational settings.

The two cases of Tatarstan and $\mathrm{BiH}$ demonstrate how schools become power arenas between competing notions of citizenship and nationhood (Staeheli and Hammet, 2010), revealing especially the precarious position of educational actors - students and teachers - in the volatile nation-building processes. In these two different geopolitical settings and in tracing the effects of temporally different pasts, we encounter similar processes that exemplify that the narratives of contested past work to form national and political communities in ways that go beyond mere different interpretations of the past events and that highlight the importance of emotional bonds formed in situ. In the case of Tatarstan, the teacher reinstates her national attachments through her emotionally and biographically embedded narrative of the conquest of Kazan and, furthermore, she gives students the possibility to engage and to relate to these narratives and memories through shared emotions. Of course, not everyone will be touched by the teacher's story in the same way, but the very act of sharing emotions through narration of historic events shows how political spaces are created in which communities are formed and identities negotiated. In the case of $\mathrm{BiH}$, two students form an intense bond and construct a shared space where the war narrative is negotiated through circulating emotions of anger, resentment, as well as intimate and sensitive attachments. This shared emotional space is crucial for performing different notions of nationhood and belonging that challenge simple narratives of ethnic hatred and division in $\mathrm{BiH}$.
Even if devoid of contesting and conflicting histories (through school curricula), educational spaces remain sites where muted narratives and emotions can unfold. Questioning such absent presences becomes then a fruitful approach to investigating political conflicts in educational spaces. Therefore, we argue for a sustained engagement with emotions in educational settings as sites of embodiment that work to negotiate and actively rework top-down educational narratives, especially when considering the processes of identitybuilding through school spaces.

To address such contested, emotionally charged narratives within classrooms becomes a particularly complex and difficult endeavor, especially within conditions where such pasts are issues that divide political communities. However, the muting of conflicting issues is problematic not only because it fails to silence the past but also because it undermines the possibility of open debate and discussion. These erased pasts can then become rallying points for manipulation by various political groups in ways that further divide social communities (Bekerman and Zembylas, 2011, 2014; Cole, 2007; McGlynn, 2009). It is crucial to give space in the classroom to discuss such controversial issues as it allows for an emotional reworking that is essential for the processes of democratic opening and an acknowledgement of disparate claims to nationhood.

Acknowledgements. We would like to thank Itta Bauer and Sara Landolt for getting us in contact with one another in a workshop they organized in 2014: "New Approaches to Children, Young People and Education - Subjects, Transitions, Spaces". That workshop sparked the conversation on the precarious position of young people in both Tatarstan and Bosnia and Herzegovina, the outcome of which is this paper. Moreover, we thank them for coordinating this theme issue, as well as for reading an earlier version of this paper and providing essential guidance. We would also like to thank the journal editor and two anonymous reviewers for their constructive critique. Finally, we extend our gratitude to the people in Tatarstan and Bosnia and Herzegovina for sharing their stories, insights, and feelings with us.

Edited by: M. Houssay-Holzschuch

Reviewed by: two anonymous referees

\section{References}

Adely, F.: Gendered Paradoxes: Educating Jordanian Women in Nation, Faith, and Progress, University of Chicago Press, Chicago, 2012.

Ahmed, S.: The Cultural Politics of Emotion, Edinburgh University Press, Edinburgh, 2004.

Athusser, L.: Ideology and Ideological State Apparatuses (Notes towards and Investigation), in: The Anthropology of the State: A Reader, edited by: Sharma, A. and Gupta, A., Blackwell, Oxford, 86-111, 2006. 
Avis, G: The Making of the Soviet Citizen: Character Formation and Civic Training in Soviet Education, Routledge, London, 1987.

Bartulović, A.: Nationalism in the Classroom: Narratives of the War in Bosnia-Herzegovina (1992-1995) in the History Textbooks of the Republic of Srpska, Stud. Ethnic. Nat., 6, 51-72, 2006.

Bekerman, Z. and Zembylas, M.: The Emotional Complexities of Teaching Conflictual Historical Narratives: The Case of Integrated Palestinian-Jewish Schools in Israel, Teach. Coll. Rec., 113, 1004-1030, 2011.

Bekerman, Z. and Zembylas, M.: Teaching Contested Narratives, Cambridge University Press, Cambridge, 2014.

Bénéi, V.: Schooling Passions: Nation, History, and Language in Contemporary Western India, Stanford University Press, Stanford, 2008.

Benwell, M.: From the Banal to the Blatant: Expressions of Nationalism in Secondary Schools in Argentina and the Falkland Islands, Geoforum, 52, 51-60, 2014.

Bieber, F.: Nationalist Mobilization and Stories of Serb Suffering: The Kosovo Myth from 600th Anniversary to the Present, Rethink. Hist., 6, 95-110, 2002.

Billig, M.: Banal Nationalism, Sage, London, 1995.

Bloch, M.: How We Think They Think: Anthropological Approaches to Cognition, Memory, and Literacy, Westview, Boulder, 1997.

Bourdieu, P.: Language and Symbolic Power, Polity Press, Cambridge, 1991.

Cairns, E. and Roe, M.: The Role of Memory in Ethnic Conflict, Palgrave, Basingstoke, 2002.

Campbell, D.: National Deconstruction: Violence, Identity and Justice in Bosnia, University of Minnesota Press, Minneapolis, 1998.

Cole, E. (Ed.): Teaching the Violent Past: History Education and Reconciliation, Rowman and Littlefield, Lanham, 2007.

Collins, D. and Coleman, T.: Social Geographies of Education: Looking Within, and Beyond, School Boundaries, Geogr. Compass, 2, 281-299, 2008.

Cough, P. T. and Halley, J. (Eds.): The Affective Turn: Theorizing the Social, Duke University Press, Durham, 2007.

Derrick, M.: The Tension Of Memory: Reclaiming The Kazan Kremlin, Acta Slavica Iaponica, 33, 1-26, 2012.

Drozdzewski, D.: Knowing (or Not) about Katyń: The Silencing and Surfacing of Public Memory, Space Polity, 16, 303-319, 2012.

Gorenburg, D.: Minority Ethnic Mobilization in the Russian Federation, Cambridge University Press, Cambridge, 2003.

Graney, K.: Making Russia Multicultural Kazan at Its Millennium and Beyond, Probl. Post-Commun., 54, 17-27, 2007.

Graney, K.: Of Khans and Kremlins: Tatarstan and the Future of Ethno-Federalism in Russia, Lexington Books, Lanham, 2010.

Hammack, P. and Pilecki, A.: Narrative as a Root Metaphor for Political Psychology, Polit. Psychol., 33, 75-103, 2012.

Hemon, A.: National Subjects, Guernica: a magazine of art \& politics, available at: https://www.guernicamag.com/ features/hemon_1_15_12/ (last access: 26 April 2016), 2012.

Hill, K.: Possibilities for Social Cohesion in Education: BosniaHerzegovina, Peabody J. Educ., 86, 155-170, 2011.
Holloway, S. L., Hubbard, P., Jons, H., and Pimlott-Wilson, H.: Geographies of Education and the Significance of Children, Youth and Families, Prog. Hum. Geogr., 34, 583-600, 2010.

Hromadžić, A.: Bathroom Mixing: Youth Negotiate Democratization in Postconflict Bosnia and Herzegovina, PoLAR: Polit. Legal Anthropol. Rev., 34, 268-89, 2011.

Hromadžić, A.: Citizens of an Empty Nation: Youth and StateMaking in Postwar Bosnia-Herzegovina, University of Pennsylvania Press, Philadelphia, 2015.

Husremović, D., S. Powell, A. Šišić and Dolić, A.: Obrazovanje u Bosni i Hercegovini: Čemu učimo djecu? Analiza sadržaja udžbenika nacionalne grupe predmeta (Education in Bosnia and Herzegovina: What are we teaching children? Content analysis of national subjects' textbooks), Sarajevo, Fond otvoreno društvo Bosna i Hercegovina, Sarajevo, 2007.

Ismailov, M. and Ganieva, N.: In Search for the Russian National Identity: Do History Textbooks Hold the Answer?, J. Alternat. Perspect. Social Sci., 5, 366-392, 2013.

Izmailov, I.: Zavoevanie Kazanskogo Khanstva: prichiny i posledstvia (The conquest of the Kazan Khanate: reasons and consequences), in: Tatarskii narod posle 1552 goda: poteri i priobriteniya, Materialy nauchno-prakticheskoi konferentsii, Kazan, 2003.

Jeffrey, C.: Geographies of Children and Youth I: Eroding Maps of Life, Prog. Hum. Geogr., 34, 496-505, 2010.

Kallio, K. and Häkli, J.: Tracing Children's Politics, Polit. Geogr., 30, 99-109, 2011.

Kappeler, A.: The Russian Empire: A Multi-Ethnic History, Routledge, New York, 2001.

Karge, H. and Batarilo, K.: Reform in the Field of History in Education Bosnia and Herzegovina, Georg Eckert Institute, Braunschweig, 2008.

Kenway, J. and Youdell, D.: The Emotional Geographies of Education: Beginning a Conversation, Emot. Space Soc., 4, 131-136, 2011.

Khasanova, G.: Nation-Building and Values in Russian Textbooks, in: Nation-Building and Common Values in Russia, edited by: Kolstø, P. and Lakkisrud, H., Rowman \& Littlefield, Lanham, 269-299, 2005.

Korostelina, K.: Constructing Nation: National Narratives of History Teachers in Ukraine, Nat. Ident., 15, 401-416, 2013.

Kuftinec, S.: (Walking Through a) Ghost Town: Cultural Hauntologie in Mostar. Bosnia-Herzegovina, or Mostar: A Performance Review, Text Perform. Quart., 18, 81-95, 1998.

Laketa, S.: Youth as Geopolitical Subjects: the Case of Mostar, Bosnia and Herzegovina, in: Politics, Citizenship and Rights, Geographies of Children and Young People, Vol. 7, edited by: Skelton, T., Springer, Singapore, 153-169, 2015.

Laketa, S.: Geopolitics of Affect and Emotions in a Post-conflict City, Geopolitics, 21, 661-685, 2016.

Levinson, B.: The Cultural Production of the Educated Person: Critical Ethnographies of Schooling and Local Practice, SUNY Press, New York, 1996.

McGlynn, C.: Peace Education in Conflict and Post-Conflict Societies, Palgrave Macmillan, New York, 2009.

Middleton, D. and Edwards, D. (Eds.): Collective remembering, Sage, London, 1990.

Mills, S. and Kraftl, P.: Cultural Geographies of Education, Cult. Geogr., 23, 19-27, 2016. 
Moore, A.: The Eventfulness of Social Reproduction, Sociolog. Theory, 29, 294-314, 2011.

Mujkić, A.: Bosna i Hercegovina između individualne i kolektivne indiferencije (Bosnia and Herzegovina between Individual and Collective Indifference), in: U okrilju nacije: Etnički i državni identitet kod mladih u Bosni i Hercegovini (In the Nation's Embrace: Ethnic and State Identity among Youth in Bosnia and Herzegovina), edited by: Majstorović, D. and Turjačanin, V., Centar za kulturni i socijalni popravak, Banja Luka, 19-32, 2011.

Müller, M.: Education and the Formation of Geopolitical Subjects, Int. Polit. Sociol., 5, 1-17, 2011.

Oglesby, E.: Educating Citizens in Postwar Guatemala: Historical Memory, Genocide, and the Culture of Peace, Radic. Hist. Rev., 27, 77-98, 2007.

OSCE: Modernizing History Teaching (Textbooks and Curriculum), OSCE, Sarajevo, 2010.

Pandey, G.: Remembering Partition: Violence, Nationalism and History in India, Cambridge University Press, Cambridge, 2001.

Parliamentary Assembly of the Council of Europe: Recommendation 1454, Education in Bosnia and Herzegovina, available at: http://www.assembly.coe.int/nw/xml/XRef/ Xref-XML2HTML-en.asp?fileid=16792\&lang=en (last access: 20 December 2016), 2000.

Perspektiva-Mostar: Dir. Sokolović, Ada, available at: http://www.slobodnaevropa.org/media/video/ perspektiva-prva-epizoda-mostar/26835252.html (last access: 26 April 2016), 2015.

Piattoeva, N.: Citizenship and nationality in changing Europe: a comparative study of the aims of citizenship education in Russian and Finnish national education policy texts, J. Curric. Stud., 41, 723-744, 2009.

Ploszajska, T.: Constructing the Subject: Geographical Models in English schools, 1870-1944, J. Hist. Geogr., 22, 388-398, 1996.

Prina, F.: National Minorities in Putin's Russia Diversity and Assimilation, Routledge, New York, 2015.

Radušić, E.: History Curriculum Analysis: Teaching History in Bosnia and Herzegovina with a Comment to the Significance of Teaching Plan and Program and their Characteristics, EUROCLIO, Sarajevo, 2009.

Reed-Danahay, D.: Education and Identity in Rural France: The Politics of Schooling, Cambridge University Press, Cambridge, 1996.

Salomon, G.: A Narrative-Based View of Coexistence Education, J. Social Issues, 60, 273-287, 2004.

Shnirelman, V.: From Social Classes to Ethnicities: Ethnocentric Views in History Textbooks in Post-Soviet Russia, J. Eurasian Stud., 2, 125-133, 2011.
Simić, A.: Nationalism as Folk Ideology: the Case of Former Yugoslavia, in: Neighbours at War: Anthropological Perspectives on Yugoslav Culture, Ethnicity, and History, edited by: Halpern, J. and Kideckel, D., PennState University Press, University Park, 103-115, 2000.

Skelton, T.: Taking Young People as Political Actors Seriously: Opening the Borders of Political Geography, Area, 42, 145-151, 2010.

Smith, A.: Myths and Memories of the Nation, Oxford University Press, Oxford, 1999.

Staeheli, L. and Hammett, D.: Educating the New National Citizen: Education, Political Subjectivity and Divided Societies, Citizenship Stud., 14, 667-680, 2010.

Strauss, A. and Corbin, J.: Basics of Qualitative Research: Techniques and Procedures for Developing Grounded Theory, Sage Publications, London, 1998.

Suleymanova, D.: Education between Regionalisation and Centralisation: Russian Education Reforms and their Implications for Schooling in Tatarstan, Europe-Asia Studies, vol. 69, forthcoming, 2017.

Toal, G. and Dahlman, C.: Bosnia Remade: Ethnic Cleansing and its Reversal, Oxford University Press, Oxford, 2011.

Torsti, P.: People's Attitudes Versus Politics: Segregated Education in Post-War Bosnia and Herzegovina, Perspect. Educ., 27, 190198, 2009.

Turjačanin, V., Kolenović-Đapo, J., Čehajić-Clancy, S., Poljac, E., Kordić, M., and Alić, M. (Eds.): Podijeljene škole u Bosni i Hercegovini (Divided Schools in Bosnia and Herzegovina), UNICEF BiH, Sarajevo, 2009.

Verdery, K.: What was socialism, and what comes next?, Princeton University Press, Princeton, 1996.

Willis, P.: Learning to Labor: How Working Class Kids Get Working Class Jobs, Columbia University Press, Morningside, 1981.

Zamyatin, K.: The Education Reform in Russia and Its Impact on Teaching of the Minority Languages: An Effect of NationBuilding?, J. Ethnopolit. Minor. Iss. Eur., 11, 17-47, 2012.

Zembylas, M.: The Power and Politics of Emotion in Teaching, in: Emotion in Education, edited by: Schutz, P. and Pekrun, R., Academic Press, Burlington, 293-309, 2007.

Zembylas, M.: The Politics of Trauma in Education, Palgrave Macmillan, New York, 2008.

Zhurzhenko, T.: 'Capital of Despair' Holodomor Memory and Political Conflicts in Kharkiv after the Orange Revolution, E. Eur. Polit. Soc., 25, 597-639, 2011. 